This is the peer reviewed version of the following article: Levy, O. (2005), The influence of top management team attention patterns on global strategic posture of firms. J. Organiz. Behav., 26: 797-819, which has been published in final form at https://doi.org/10.1002/ job.340. This article may be used for non-commercial purposes in accordance with Wiley Terms and Conditions for Use of Self-Archived Versions.

\title{
THE INFLUENCE OF TOP MANAGEMENT TEAM ATTENTIONAL PATTERNS ON GLOBAL STRATEGIC POSTURE OF FIRMS•
}

\author{
Orly Levy
}

Cite as follows:

Levy, O. (2005). The influence of top management team attention patterns on global strategic posture of firms. Journal of Organizational Behavior. 26(7):797-819.

- Special thanks to Schon Beechler, Mason Carpenter, Yitzik Saporta, and Yehouda Shenhave for their insightful and helpful comments on earlier drafts of this manuscript. 


\title{
THE INFLUENCE OF TOP MANAGEMENT TEAM ATTENTIONAL PATTERNS ON GLOBAL STRATEGIC POSTURE OF FIRMS
}

\begin{abstract}
Drawing upon the managerial cognition and the upper echelons perspectives, this study proposes that the cognitive capabilities of top executives significantly affect globalization efforts. Specifically, the study suggests that managerial attention patterns or the cognitive processes of 'noticing and constructing meaning' about the environment influence strategic posture of firms. Based on a longitudinal sample of U.S. firms operating in technologically intensive industries, the results indicate that firms were more likely to develop an expansive global strategic posture when their top management paid attention to the external environment and considered a diverse set of elements in this environment. On the other hand, firms led by top management that paid more attention to the internal environment were less likely to be global.
\end{abstract}

Key words: Managerial Attention, Top Management Team, Globalization Strategies 
As the processes of globalization continue to transform the competitive landscape and the structure of business opportunities, firms are encouraged to expand their operations and markets globally (Bartlett \& Ghoshal, 1989; Porter, 1986; Sanders \& Carpenter, 1998). While the majority of large U.S. companies operate overseas to some extent, many companies did not respond vigorously to the globalization challenge and "still rely on their 'home base' as the center for their economic activities" (Hirst \& Thompson, 1999). While empirical research has pointed to a host of factors affecting firm-level variation in the propensity to expand globally, it largely overlooked the question of whether top management team cognition is related to global strategies of their firms (Bartlett \& Ghoshal, 1991; Doz \& Prahalad, 1991; Schendel, 1991). However, the incorporation of a cognitive perspective is warranted by recent developments in the global economy that have created an increasingly complex decision-making environment characterized by information overabundance, uncertainty, and ambiguity. Consequently, top management has to develop considerable cognitive abilities if it is to recognize and capitalize upon opportunities for global expansion (Bartlett \& Ghoshal, 1989; Prahalad, 1990; Prahalad \& Doz, 1987). Not surprisingly, Govindarajan and Gupta (1998:2) went so far as to suggest that "[global] success is all in the mindset."

However, with relatively few exceptions (e.g., Calori, Johnson, \& Sarnin, 1994; Murtha, Lenway, \& Bagozzi, 1998), empirical research did not specifically and systematically examine the mindsets of executives in the context of globalization. Rather, the majority of research in this area has used demographic variables as proxies for underlying cognitive capabilities and processes, thereby "black-boxing” cognitive variables of interest (Carpenter \& Fredrickson, 2001). Consequently, the properties of managerial cognition most likely to affect important globalization decisions remain relatively opaque and under-specified. Moreover, while cognitive constructs such as "global mindset" (Rhinesmith, 1992) and "transnational mentality" (Bartlett \& Ghoshal, 1989) 
have come to be associated with a variety of organizational phenomena, empirical research rarely tested the presumed link between managerial cognition and globalization-related organizational outcomes.

The purpose of this study is to address this gap in existing research. The research draws on complementary literatures to examine the idea that globalization-related strategic choices are related to top management team cognition. Specifically, this study examines the relationship between top management attentional patterns and global strategic posture and suggests that the cognitive processes of 'noticing and constructing meaning' about the environment are reflected in the global strategies of firms. By testing theoretically grounded propositions about the relationship between top management attentional patterns and global strategic posture, we can begin to explicate the properties of managerial cognition most likely to affect strategic choices of firms in the context of globalization. Furthermore, by incorporating a cognitive perspective into the research on global strategies, we can gain an improved understanding of the factors shaping globalization-related strategic choice.

\section{THEORY DEVELOPMENT AND HYPOTHESES}

The managerial cognition perspective and the upper echelons research tradition provide this study with a theoretical framework, linking top management teams' cognition to global strategic posture. The managerial cognition perspective suggests that information-processing capabilities of senior managers exert significant influence over a variety of organizational phenomena, including strategic decisions (Barr, Stimpert, \& Huff, 1992; Clapham \& Schwenk, 1991; Ginsberg, 1989; Stubbart, 1989). Similarly, the upper echelons perspective views the organization as a reflection of its top managers: "organizational outcomes--both strategies and effectiveness--are viewed as reflections of the values and cognitive bases of powerful actors in the organization" (Hambrick \& Mason, 1984:193). These assertions are rooted in the observation that senior managers interpret 
issues relevant to strategic decision-making and possess the power necessary for implementing choices derived from those interpretations (Hambrick \& Mason, 1984). In addition, these propositions are predicated on the recognition that the concept of strategy consists not merely of a chosen position, but of an integrated way of interpreting and "enacting" the business environment (Daft \& Weick, 1984; Smircich \& Stubbart, 1985).

Recent developments in the global economy have engendered a "cognitive revolution" in the area of international management, bringing the cognitive capabilities of managers to the forefront (Doz \& Prahalad, 1991; Prahalad, 1990). Kanter (1994:232), for example, argues that "global thinking is what's important for companies today, not international operations." Similarly, Govindarajan and Gupta (1998) suggest that the success of companies in seizing opportunities in the global marketplace and confronting emerging challenges depends crucially on how intelligent they are at observing and interpreting global dynamics. Indeed, many authors have singled out the cognitive capabilities of senior managers as the critical infrastructure of present-day companies, significantly affecting globalization efforts (Bartlett \& Ghoshal, 1990; Doz \& Prahalad, 1991; Kanter, 1994). This growing recognition, however, did not generate much empirical work on the relationship between managerial cognition and globalization strategies. The section below examines a significant aspect of these cognitive capabilities—attention —and examines its potential strategic consequences.

\section{Top Management Team Attentional Patterns and Global Strategic Posture}

Global strategic posture reflects the degree to which firms develop a global presence and come to depend on foreign operations and markets for creating and sustaining competitive advantage (Sullivan, 1994). Through extensive global operations, firms can leverage R\&D costs and tap into critical knowledge sources, which are globally dispersed (Bartlett \& Ghoshal, 1989; 
Chiesa, 1996; Nohria \& Ghoshal, 1997). These advantages are especially critical for firms operating in technologically intensive industries given the mounting costs of R\&D activities and the significance of innovation to organizational competitiveness (Ghoshal \& Bartlett, 1988; Vernon, 1966; Wolfe, 1994).

However, developing expansive global presence presents top management with the challenge of breaking away from a domestic mindset, which filters the world through a local perspective, and adopting a mindset that spans the globe (Bartlett \& Ghoshal, 1990; Ohmae, 1989). In other words, in order to recognize and capitalize upon opportunities for expansion beyond the domestic market, top management needs to scan the external environment from a broad perspective and to consider business threats and opportunities that emerge worldwide (Bartlett \& Ghoshal, 1990). In this context, top management attention to the external environment constitutes a first and necessary step toward developing expansive global strategic posture.

Although studies have not yet linked managerial attentional patterns to globalization-related strategic choice, the influence of managerial attention on strategic behavior of firms has long been theoretically recognized and empirically documented (e.g., D'Aveni \& MacMillan, 1990; Kiesler \& Sproull, 1982; Ocasio, 1997; Sproull, 1984). Ocasio (1997:186), for example, argues that "What decision-makers do depends on what issues and answers they focus their attention on." Attention is defined as that which occupies top managers' consciousness (Fiske \& Taylor, 1984) or in processual terms "allocating information-processing capacity [...] to environmental stimuli over time" (Sproull, 1984:10). Sproull (1984:10) and others (e.g., Abrahamson \& Fombrun, 1994; Daft \& Weick, 1984; Hambrick \& Mason, 1984; Ocasio, 1997;) suggested that attention instigates complex cognitive processes that go beyond simply "paying attention" to something:

When a manager is attending to a particular stimulus he is processing information relevant to it... This definition [of attention] is broader than the psychological concept of attention. It includes the overt, visible steps of receiving and disseminating information that are 
captured in the common-place phrase, "paying attention to," as well as the mental steps of noting and encoding... Although the internal, mental aspects of attention remain hidden, the

concept can prove useful in systematic investigations of managerial information processing.

Analytically, attention is considered the first step of a tripartite information processing sequence that involves attention, interpretation, and action (Abrahamson \& Fombrun, 1994; Daft \& Weick, 1984). First, top managers have limited information-processing capacity and therefore attend to only certain facets of the environment while ignoring others (Sproull, 1984). Second, environmental information undergoes interpretation that gives structure and meaning to the data (Daft \& Weick, 1984). Third, these interpretations influence top managers' actions (Daft \& Weick, 1984; Dutton \& Duncan, 1987; Kiesler \& Sproull, 1982). Attention is therefore considered a crucial component of managerial behavior, affecting subsequent interpretation and future action (Kiesler \& Sproull, 1982).

\section{Allocating Attention between the External and Internal Environments. Previous}

research on managerial attention suggests that attention to the external environment may promote the development of expansive strategic posture whereas attention to the internal environment may hinder this development. In a rapidly changing environment, attention to the external environment has been associated with strategic adaptation and innovation while attention to the internal environment has been associated with strategic maladaptation and inertia (D'Aveni \& MacMillan, 1990; Geletkanycz \& Hambrick, 1997). D'Aveni and MacMillan (1990), for example, found that firms led by top management teams that paid more attention to the external environment were more likely to adapt to changing circumstances and to survive crisis situations than firms led by teams that paid more attention to the internal environment.

Attention to the external environment may be crucial in the development of expansive global strategic posture since managers who focus their attention on the external environment scan it vigilantly and are therefore more likely to notice diverse events, changes, and trends in this 
environment (Aguilar, 1967; D'Aveni \& MacMillan, 1990; Hambrick, 1982). Consequently, they are more likely to notice environmental changes and to recognize emerging opportunities for global expansion. Moreover, these cognitive processes of noticing and the ensuing processes of interpretation can potentially lead to the construction of new mental models (Barr et al., 1992) that re-delineate the boundaries of the environment as to encompass foreign markets and redefine the repertoire of viable strategic choices as to include global expansion. Thus, the processes of 'noticing and constructing meaning' (Kiesler \& Sproull, 1982) about the external environment can lead to strategic action in the global arena that capitalizes upon opportunities for global expansion. Therefore, we suggest that top management that focuses its attention on the external environment is more likely to notice opportunities for global expansion and venture into an unfamiliar strategic arena in pursuit of expansive global activities:

\section{Hypothesis 1: $\quad$ Top management team attention to the external environment will be positively related to the expansiveness of global strategic posture of the firm.}

As noted earlier, managers have only a limited information processing capacity and therefore allocate their attention among various aspects of the environment. In this respect, the total amount of attention is considered finite and distributed among various facets of the environment (Sproull, 1984). Thus, managers who focus their attention on the internal environment often pay less attention to the external environment and therefore are less likely to notice opportunities for global expansion. Moreover, managers who overlook changes in the external environment are less likely to reevaluate their "domestic" mental models and to consider global expansion as a viable strategic choice. Therefore, we would hypothesize that top management that focuses its attention on the internal environment is less likely to develop an expansive global strategic posture: 


\title{
Hypothesis 2: $\quad$ Top management team attention to the internal environment will be negatively related to the expansiveness of global strategic posture of the firm.
}

\begin{abstract}
Allocating Attention among Aspects of the External Environment. While attention to the external environment may play an important role in shaping global strategic posture of firms, allocating attention among various aspects of the external environment is also crucial (Govindarajan \& Gupta, 2001; Kedia \& Mukherji, 1999; Rhinesmith, 1992). Rhinesmith (1992:64) suggests "people with global mindsets are constantly scanning the geographical horizon to learn more about potential markets and competitors, new technology, and new suppliers." Thus, as threats and opportunities emerge worldwide, the capacity of top management to pay attention to diverse elements, trends, and events may be associated with global expansion. This additional aspect of managerial attention reflects breadth of attention or the extent to which top management attends to diverse elements and markets in the external environment. It is based on the assumption that while top management may be externally oriented, it still may scan the environment through a narrow and simple perceptual lens. For example, top management may focus exclusively on a salient facet of the external environment, say customers, while ignoring other elements in the environment such as competitors or dealers. Similarly, in a global context, top management may pay attention to the global environment, but focus predominantly on one or two foreign regions, often on culturally and psychically familiar ones. However, developing an expansive global presence and capitalizing upon emerging market opportunities around the globe often requires allocating attention to diverse elements in the environment. In this respect, top management that scans the external environment through a broad perceptual lens may develop an expansive global strategic posture. On the other hand, top management that utilizes a narrow perceptual lens is more
\end{abstract}


likely to overlook changing environmental dynamics and consequently remain within the narrow confines of the strategic status quo.

Indeed, a few studies that examined attention to environmental changes and contingencies suggest that the capacity of managers to capture and represent a wide range of environmental changes and to reevaluate and update their cognitive models is a significant step toward strategic innovation and organizational adaptation (Barr et al., 1992; Lant, Milliken, \& Barta, 1992). Therefore, we hypothesize that top management team breadth of attention to the external environment may promote strategic innovation in the global arena and will be related to global strategic posture.

\section{Hypothesis 3: Top management team breadth of attention to the external environment will be positively related to the expansiveness of global strategic posture of the firm.}

\section{RESEARCH METHODS}

\section{Sample}

As this study focuses on managerial cognition, a sample was drawn from three technologically intensive industries in the US: computer, pharmaceutical, and semiconductor. These industries are all characterized by high rate of change, dynamism, and complexity characteristics that place high levels of information-processing demands on top management (Henderson \& Fredrickson, 1996) In addition, these industries are considered high discretion industries (Finkelstein \& Hambrick, 1996), a characteristic that affects both managerial attention patterns (Abrahamson \& Hambrick, 1997) and the relationship between attention and strategic choice (Finkelstein \& Hambrick, 1990). These particular industries were selected for three other reasons. First, all of these industries are highly technologically intense (Business Week, 1989) and 
relatively internationalized (Bureau of Economic Analysis, 1985). Second, each industry is a widely recognized industry grouping among both managerial and financial communities. Thus, information specifically pertaining to these industries is readily available. Finally, a sufficient number of publicly held companies in each of these industries during the appropriate period allowed for a statistically adequate sample of firms.

Potential sample firms were identified using the Compact Disclosure database, per SIC code. Consistent with the observations that Standard Industry Classification (SIC) codes are helpful in resolving the problem of industry boundaries (e.g., Scott \& Meyer, 1991), industry classification was confirmed throughout the period of the study by examining primary SIC codes at the four-digit level for semiconductor (SIC 3674) and pharmaceutical (SIC 2834 ) and at the three-digit level for computer (SIC 357) firms. ${ }^{1}$ The final sample of 69 firms included 30 computer, 16 pharmaceutical, and 23 semiconductor firms.

As discussed in more detail below, archival data were collected from 1987 through 1994 for the independent variables and from 1987 through 1996 for the dependent variable. The choice of this time frame was informed by an analysis performed by Hirst and Thompson (1999) of the global activities of over 500 manufacturing MNCs from five countries, including the US. This analysis suggests that in 1987 American manufacturing MNCs were still home-centered (Hirst \& Thompson, 1999). While the industries examined in this study were relatively internationalized, individual firms were not uniformly global. Thus, examining the sample from 1987 onward over an eight-year period was meant to capture possible changes and variation in the global activities of firms.

\footnotetext{
${ }^{1}$ The use of a broader SIC code for the computer industry was necessary due to a change in the Standard Industrial Classification system in 1987. Until 1987, all computer firms included in the sample shared the same SIC code (3573) and the majority of them continued to use this code until 1990.
} 


\section{Measures}

\section{Global strategic posture}

Global strategic posture (GSP) reflects the relative significance of foreign markets and operations in sustaining the firm, as well as their geographic dispersion (Sullivan, 1994). This definition is consistent with prior research on internationalization and provides a sound basis for comparative examination (Carpenter, Sanders, \& Gregersen, 2001; Sullivan, 1994). GSP was measured by a variation on the composite measure developed by Sullivan (1994). The first dimension, foreign sales, reflects the relative significance of foreign market and was calculated as a ratio of foreign sales to total sales. The second dimension, foreign production, reflects the degree to which a firm depends on foreign-owned assets and resources and was measured as a ratio of foreign assets to total assets. The third dimension, geographic dispersion, roughly reflects the cultural and psychic diversity associated with globalization of operations and markets as indicated by the other two dimensions (O'Grady \& Lane, 1996; Ronen \& Shenkar, 1985). Geographic dispersion was measured using the number of foreign countries in which a firm maintains a subsidiary as a percentage of the highest number of countries represented among the sample firms. Indicators of the three dimensions discussed above were combined to form a composite measure of GSP. Specifically, each of the three indicators was converted to a ratio and standardized as suggested by Ramaswamy, Kroeck, and Renforth (1996). These three z-values were summed to create a single score measure, GSP. GSP has a Cronbach's alpha of 0.83, indicating acceptable reliability. Principal Component Analysis indicated that a single unambiguous factor comprises GSP with eigenvalue of 2.224 and loadings of 0.865 (foreign sales), 0.924 (foreign production), and 0.789 (geographic dispersion). Geographic segment data were extracted from Standard and Poor's COMPUSTAT. Data on foreign subsidiaries were collected from Dun's Directory of 
American Corporate Families and International Affiliations as well as from annual reports and 10K statements.

\section{Measuring Attention}

In order to determine attention patterns of top management, letters to shareholders published in annual reports were treated as a reflection of the perceptual focus of the team and analyzed their content. Content analysis of written and oral communications is a particularly effective method for constructing perceptions and cognitions of their authors (Holsti, 1968), reflecting "traces of an author's world view at a point in time and immune to retrospective construction" (Barley, Meyer, \& Gash, 1988:27). Furthermore, the analysis of language provides an unobtrusive access to the cognitive structures through which individuals perceive and construct the world, since language reflects mental structure and processes (Berger \& Luckmann, 1966; Sapir, 1944; Whorf, 1956).

Content analysis of letters to shareholders has been used effectively to examine a wide range of issues, including managerial attention and attribution patterns (Bettman \& Weitz, 1983; Clapham \& Schwenk, 1991; D'Aveni \& MacMillan, 1990) and corporate strategy and risk (Bowman, 1984). Letters to shareholders offer a fairly open stage for top management to express its views and therefore provide a particularly good window into major issues and arenas that are of interest and concern to senior managers, revealing how much attention is paid to various aspects of the environment, relative to others (D'Aveni \& MacMillan, 1990). Additionally, the letters reflect the worldviews and perspectives of top management as a team because they are usually the products of a collective and consensual process at the apex of the organization (Abrahamson \& Hambrick, 1997; Salancik \& Meindl, 1984). Therefore, letters to shareholders can be viewed as managerial artifacts, reflecting the business, technological, and geographic worlds to which top executives attend. 
Nevertheless, several researchers have raised concerns whether letters to shareholders constitute an adequate and valid data source for studying managerial cognition (e.g., Abrahamson \& Hambrick, 1997; Huff, 1990). One shortcoming of using letters to shareholders is that their authors are unknown. Abrahamson and Hambrick (1997), however, argue that anecdotal evidence suggests that letters to shareholders are the products of a collaborative effort by top managers. Even if letters to shareholders were written by top management, the question of whether they reflect the cognitive orientation of top management remains valid. Thus, it is necessary to examine studies that specifically analyzed letters to shareholders in order to assess whether data drawn from these letters constitute a valid measure of top management cognitive orientation (Abrahamson \& Hambrick, 1997). Several studies (e.g., Bettman \& Weitz, 1983; Bowman, 1984; Clapham \& Schwenk, 1991; Fiol, 1995; Huff \& Schwenk, 1990) have been designed explicitly to test the validity of cognitive measures derived from letters to shareholders. Three of these studies, which examined patterns of casual attribution in annual reports, provide considerable evidence that casual attribution processes are better explained by cognitive theories than by impression management theories (Bettman \& Weitz, 1983; Clapham \& Schwenk, 1991; Huff \& Schwenk, 1990). These studies support the conclusion that letters to shareholders constitute valid measures of top management casual reasoning. A third study by Fiol (1995), while qualifying this conclusion, offers unique additional support. Fiol compared public and private documents generated by executives in the forest products industry. She found that non-evaluative cognitions-attribution of control - were significantly correlated across these two types of documents, supporting the conclusion of the previous three studies. She also found, however, that the evaluative cognitions (positive/negative) of the two sets of documents were not significantly correlated. Fiol (1995) concluded that non-evaluative statements tend to reflect managerial cognitions, whereas evaluative statements in public documents more likely reflect impression management. In addition, several 
other studies (e.g., Bowman, 1978; D’Aveni \& MacMillan, 1990; Fiol, 1989) provide evidence for the construct validity of managerial cognition measures derived from letters to shareholders by testing theoretical relationships between these measures and other variables (DeVellis, 1991).

More generally, it should be noted that criticism of managerial cognition measures derived from letters to shareholders also pertains to other attempts at quantifying cognition (Abrahamson \& Hambrick, 1997). Thus, any critique must consider the relative advantages this method provides over other methods for studying top management cognition. Clearly, using letters to shareholders provides an unobtrusive access to managerial cognition and allows testing theoretical propositions containing longitudinal aspects.

\section{Measures of Attention to the External and Internal Environments. Attention was} measured as attention paid to a specific element of the environment in the letter to shareholders. Following the stakeholders' approach to organizations (Freeman, 1984) and the open systems approach, attention to the external environment was measured as the attention paid in the letter to the following five external environmental elements: competitors, customers, dealers, strategic partners, and foreign-related aspects of the environment. The last category of environmental elements includes references to foreign operations and markets, economic conditions in foreign countries, and international capital markets. Attention to the internal environment was measured as the attention paid in the letter to the following four classes of internal environmental elements: Board of Directors, employees, owners, and top management.

Using these nine first-order attention variables, attention was measured in two ways: (1) Absolute attention - a summative measure of the number of sentences in each letter referring to a facet of the environment, say external; (2) Proportionate attention was used in order to control for the length of the letter by dividing the number of sentences devoted to a facet of the environment in the letter, say external, by the number of words in each letter. The absolute and proportionate 
measures of external and internal attention distinguish between "amount" and "degree" of attention as D'Aveni and MacMillan (1990) did in their study of top management attentional patterns.

Measures of Attention Breadth. In measuring attention breadth across the external environment, the number of sentences referring to the following ten environmental elements were considered: competitors, customers, dealers, strategic partners, Africa, Asia-Pacific, Europe, the Middle East, Latin America, and North America. Each foreign region is characterized by a unique "cognitive map" of principles of management (Hofstede, 1993:94), presenting different challenges and obstacles. Therefore, measuring the "psychic dispersion" across these six foreign regions estimates the extent to which top management cognitive orientation spans across the globe (Sullivan, 1994). These ten environmental elements were combined, creating a ten-category index. Finally, attention breadth was measured in two ways: (1) Absolute attention breadth - the number of elements to which top management attends out of the ten possible external and regional elements. This measure has a theoretical range of 0-10; (2) Proportionate attention breadth- this measure takes into account both the number of distinct elements in each of the ten categories to which top management attends and their relative significance. It was computed by variation of the Herfindal-Hirschman index, which is suitable for categorical variables, as follows:

$$
A B=\operatorname{in}_{\mathrm{i}=1}^{10}-\sum\left(P_{i}\right)^{2}
$$

where $A B$ is the attention breadth measure and $p$ the percentage of sentences referring to each of the ten environmental categories.

Content analysis procedure. Both manual and computer-aided content analysis methods were used in order to gain in-depth familiarity with the letters and to assure reliability of the content analysis procedure. The process of dictionary construction began with manual coding of a 
substantial number of letters that provided a basis for the creation of a computer-based dictionary. The dictionary included nine principal categories, each of which contained a variety of words and phrases referring to the nine attention variables described above. In essence, the dictionary was designed to identify frequencies of higher level concepts such as 'customers' and 'foreign operations and markets' that are types of abstractions encompassing conceptually similar lexical terms of greater specificity. However, establishing categorical membership of lexical terms is quite difficult because lexical items have fuzzy membership boundaries and the meaning of any word or phrase is context dependent (Smith, 1995). Resolving the issue of multiple meanings and identifying the words and phrases that carry specific meaning in a given context requires substantial domainspecific knowledge (Wade, Porac, \& Pollock, 1997). Researchers who have pursued a similar path of dictionary construction have relied on an iterative method where each term's membership is established via repeated cycles of generating potential domain-specific words and phrases, manual validation, crosstabulation, and statistical analysis (e.g., Fan, 1988; Wade et al., 1997). Consequently, generating a domain-specific dictionary that allows for automated identification of words and phrases within each category involves an enormous investment of time in dictionary building.

Following this method of abstraction and through iterative manual examination of lexical items and statistical analysis, a nine-category dictionary was constructed. The dictionary was refined by clarifying the lexical members of each of the nine categories and by excluding nondiagnostic items. While complete accuracy in any method of text analysis, whether manual or automated, is unattainable, the process of dictionary construction utilized in this study was both methodical and comprehensive and based on in-depth familiarity with the domain and texts. A more detailed description of the dictionary-building process is presented in the Appendix. 
All 526 available letters to shareholders were coded automatically using the constructed dictionary. The automated process identified all sentences referring to first-order attention variables. The following sentence, for example, was automatically coded as a reference to foreign operations and markets: "Further, to ready ourselves for the global marketplace, we have formed a coordinating group in Brussels to actively pursue new opportunities that are expected to arise from the integrated European economy." Finally, a total of 15,058 references to first-order variables were recorded in the letters. Table 1 presents descriptive statistics for all first-order attention variables. There are several patterns worth noting. First, customers is by far the most dominant external environmental element, with almost twice as many references to customers as to the second leading external category-competitors. Second, Europe was found to be the most dominant regional category, eclipsing all other five regional categories. Finally, more than 25 percent of firms' letters to shareholders did not make even a single reference to foreign-related aspects of the environment. Not surprising, independent-samples t-tests revealed that top management teams of these firms were significantly less heterogeneous in organizational tenure, age, functional background, and education specialty.

Letters to shareholders were drawn from several sources, including Compact Disclosure and online filing with the Security Exchange Commission. It should be noted that a great deal of effort went into maximizing the number of letters coded, including searching several archives and purchasing letters from a commercial database of annual reports.

\section{$\underline{\text { Insert Table } 1 \text { about here }}$}

Control variables. Top management team (TMT) demographic heterogeneity is typically associated with diversity of cognitions, skills, and network ties (Hambrick, Cho, \& Chen, 1996; Jackson \& Bantel, 1989; Wiersema \& Bantel, 1992) and may affect team attentional patterns as well as strategic choice (Carpenter \& Fredrickson, 2001; Finkelstein \& Hambrick, 1996; Hambrick 
\& Mason, 1984). Therefore, measures of demographic heterogeneity of TMT in organizational tenure, age, functional background, and education specialty were included as controls. Following Bental and Jackson (1989), Michel and Hambrick (1992) and Wiersema and Bantel (1992) functional background heterogeneity and educational specialty heterogeneity of TMT were measured by a variation of the Herfindal-Hirschman index. Functional background of team members was coded using an eight-category schema: Sales and Marketing, HR \& Administration, Production and Operation, Research and Development, Engineering, Finance and Accounting, Law, and General Management. Educational specialty was coded using a 5-ctegory schema: Arts, Sciences, Engineering, Business and Economics, Law. Absent any other indication of education specialty, TMT members with M.S. or B.S. degrees were coded as science specialists. Executives with Ph.D. degrees in the sciences were also coded as science specialists (Wiersema \& Bantel, 1992). Organizational tenure and age heterogeneity were measured using the coefficient of variation, defined as the standard deviation divided by the mean. In addition, team size may affect the depth and breadth of cognitive resources and capabilities of top management team and moderate the influence of individual executives (e.g., Finkelstein \& Hambrick, 1996; Smith et al., 1994). Therefore, team size was included as a control variable and was measured as the number of executives on the top management team above the level of Vice President. TMT members were identified through annual reports. Data on TMT characteristics were drawn from Dun and Bradstreet's Reference Book of Corporate Management.

In addition, three firm level characteristics were included as controls. The technological environment constitutes one of the most significant environments that may considerably shape information-processing of top management (Henderson \& Fredrickson, 1996). Moreover, technological intensity of the firms also may affect globalization strategies (Hitt, Hoskisson, \& Kim, 1997; Pearce, 1993). Therefore, in order to control for the potential impact of technological 
intensity on managerial cognition and on globalization strategies, the degree of technological intensity of the firm was included as a control and measured by ratio of R\&D expenditures to sales (Kobrin, 1994). Organizational slack represents those resources that are readily recoverable and would be accessible for further global expansion and was measured using a formula developed by Bourgeois and Singh (1983). Firm Size was measured as the natural log of total assets.

Temporal ordering of measures. The independent variables were observed in year $t$, global strategic posture in year $t+2$, while controlling for additional factors, including global strategic posture present at year t. The two-year lag period, as opposed to longer or shorter periods between top management team and global strategic posture observations, reduced the possibility of other factors confounding the relationship between the independent and dependent variables while allowing enough time for potential top management team effects to manifest themselves (Carpenter \& Fredrickson, 2001). A similar lagging design has been incorporated in other top management studies (e.g., Carpenter \& Fredrickson, 2001; Geletkanycz \& Hambrick, 1997) in recognition that the effects of top management on organizational outcomes are less than immediate. With this design and the support of a relatively strong theoretical foundation, we enhanced out ability to interpret the influence of top management team attentional patterns on global strategic posture, rather than the reverse. Nevertheless, this study cannot rule out other causal directions or explanations.

\section{Data Analysis}

The data contain 552 firm-year observations. These cross-sectional and time-series observations are amenable to a pooled time-series methodology in which cross-sections are aggregated across years. Employed by a growing number of organizational researchers (e.g., 
Finkelstein \& Hambrick, 1990; Haleblian \& Finkelstein, 1993; Hambrick et al., 1996), this method permits consolidated use of the full dataset, producing results that reflect the average effect of the independent variables over the full study period. Due to a larger sample size, more precise statistical estimates can be obtained.

Since pooling violates the ordinary least squares (OLS) assumptions of independence of observations (Baltagi, 1998), the hypotheses were tested using a generalized least squares model (GLS) incorporating corrections for firm-specific autocorrelation and contemporaneous correlations between cross sections, as well as for heteroscedasicity among inter-firm residuals. Specifically, we employed the Parks-Kmenta's (Parks, 1967; Kmenta, 1986) autoregressive model for pooled time series data to correct for serial and contemporaneous correlations and for panel heteroscedasicity. After these transformations, the regression model parameters were estimated using GLS. Since corrected GLS regression models were used, R-squares cannot be reliably interpreted (Kmenta, 1986) and, therefore, are not reported here.

This procedure requires a balanced design of firms and years and therefore missing data present an obstacle. Sixteen out of 69 sample firms had one or two missing letters, a total of 26 missing letters out of the 552 potentially available letters (or less than 5 percent). In order to avoid losing valuable data, missing values of measures derived from letters were replaced by the mean value of the variable in a given year. In addition, 13 out of 69 sample firms had incomplete data on TMT demographic characteristics. Therefore, the analyses that included demographic variables were run on a sub-sample of 56 firms (448 firm-year observations).

\section{RESULTS}

Descriptive statistics and correlation coefficients for all the variables are presented in Table 2. The correlation coefficients should be interpreted with caution because the data have been pooled. Nevertheless, there are several patterns worth noting. Predictably, the various measures 
developed to estimate the same underlying theoretical construct were highly intercorrelated and were therefore included in separate regression models. Second, all the pertinent attention variables were correlated with GSP both at time $t$ and $t+2$. These preliminary results are consistent with the hypotheses linking managerial attentional patterns to organizational outcomes. Third, out of the TMT heterogeneity measures, functional, educational and tenure heterogeneity are positively correlated with GSP, while age heterogeneity is negatively correlated. Finally, both firm size and organizational slack were correlated with global strategic posture, positively for size and negatively for slack. This suggests that firms with expansive global strategic posture were larger and had less slack than other firms.

\section{Insert Table 2 about here}

As mentioned above, the hypotheses were tested using corrected GLS regression models. All regression results are presented in Table 3. Due to missing data on TMT heterogeneity measures, two sets of regression analyses were performed. The first set of regression analyses were performed on the full sample (556 firm-year observations) and the results are presented in Model 1 through Model 3. Model 1 includes the control variables while Model 2 and Model 3 add the attention variables needed to test the main effects. Model 2 tests main effects of the absolute attention variables and Model 3 tests the effects of the proportionate attention variables. The second set of regression analyses, which included TMT heterogeneity measures as additional control variables, were performed on a sub-sample (448 firm-year observations). The results are presented in Model 4 through Model 6.

Turning to the external attention variables, Hypotheses 1 posited that top management team attention to the external environment will be positively related to global strategic posture. The results provide support for this proposition across all regression models. Consistent with expectations, external attention was significantly positively related to the expansiveness of global 
strategic posture, suggesting that top management teams that focused on the external environment were more likely to develop extensive global operations. Hypothesis 2 posited that top management team attention to the internal environment will be negatively related to global strategic posture. The results provide an almost consistent support to this proposition. In three out of the four regression models attention to the internal environment is negatively related to global strategic posture. Hypothesis 3 posited that top management breadth of attention will be positively related to the expansiveness of global strategic posture. This proposition was supported across all regression models, indicating that top management teams that focused on a wider spectrum of elements in the external environment were more likely to develop expansive global strategic posture. In summary, the GLS regression results provide an almost consistent support for the propositions linking top management attentional patterns with the expansiveness of global strategic posture. The coefficients of the attention variables indicate that regardless if they were measured in absolute or proportionate terms, the association between top management attentional patterns and global strategic posture was maintained. The robustness of these findings is further supported by a comparison between the results of the first sets of regression models and the second set that included the heterogeneity measures. This comparison indicates that the inclusion of the TMT heterogeneity measures almost did not change the association between attentional patterns and global strategic posture. This suggests that the relationship between the independent variables and the set of heterogeneity control variables does not change in any meaningful way the effect of attentional patterns on global strategic posture.

\section{Insert Table 3 about here}

Several control variables also showed significant effect on global strategic posture. Of particular interest are the TMT heterogeneity measures. Consistent with prior research (e.g., Carpenter \& Fredrickson, 2001), TMT tenure and educational specialty heterogeneity were 
significantly positively related to GSP in Model 4 that included the control variables only. However, when the attention variables were introduced into the regression models, these effects disappeared. In contrast, and contrary to expectations, age heterogeneity exhibited a negative relationship with GSP in two out of the three regression models. These results remained consistent when standard deviation rather than the coefficient of variation was used to measure age heterogeneity. Predictably, GSP at time $t$ was positively related to GSP at $t+2$ across all regression models. Hence, it appears that firms already engaged in global expansion are more likely to persist in this direction and to further capitalize on past investments and on knowledge and resources acquired in previous years. Technological intensity was consistently negatively related to GSP in the full sample regression models. This effect, which is inconsistent with recent evidence that suggest that R\&D intensity is positively related to globalization activity (Hitt et al., 1997; Pearce, 1993), disappeared when TMT heterogeneity measures were introduced into the regression models. The results regarding slack, firm size, top management team size, were somewhat inconsistent across the regression models. In those instances where a significant relationship was found, organizational slack was positively related to global strategic posture, indicating that availability of resources affects the magnitude of global strategic posture. Firm size was also found to be positively related to global strategic posture although the results were inconsistent. In the case where TMT size was found to be significant, it was positively associated with global strategic posture. However, an examination of the Pearson correlation table indicates that team size is intercorrelated with firm size. Thus, the effects of team size may in fact reflect the effects of organizational size, further suggesting that larger firms are more likely to develop extensive global operations.

In order to further substantiate the findings reported above, the issue of possible reverse causality was examined with a sub-sample of firms that were the least globalized during the first 
two years of this study (1987-1988). We selected firms that were consistently at the first and second percentile of GSP during this period. This selection method yielded thirteen firms that consistently sold less than $10 \%$ of their output to foreign markets and none of their assets were located overseas. Thus, since these thirteen firms were hardly or not at all globalized, their attention patterns cannot be explained as reflecting their current degree of globalization. Using the same regression analysis method outlined above, this sub-sample over an eight-year period (104 firm-year observations) was examined. ${ }^{2}$ All the main effect variables, except absolute external attention breadth, were significantly associated with global strategic posture in the hypothesized direction. These results, while restricted to a small number of firms, provide additional support to the propositions linking managerial attention patterns to global strategic posture.

\section{DISCUSSION}

Over the past decade, several researchers have argued that the emerging global environment mandates nothing less than a paradigmatic shift where the cognitive capabilities of senior managers constitute the basic unit of analysis (Bartlett \& Ghoshal, 1989; Doz \& Prahalad, 1991). Empirical research, however, rarely considered the influence of managerial cognition on globalization strategies. Therefore, the primary objectives of this study were to bring cognition to the forefront of the discussion on globalization and to identify the patterns of managerial attention most likely to affect globalization efforts. This was done by examining attentional patterns of top management teams over an eight-year period and by testing the relationship between these patterns and global strategic posture of firms. In support of the proposition that managerial cognition is related to globalization strategy, the results indicate that top management teams that focus on the external environment and attend to diverse elements in this environment were more likely to pursue

\footnotetext{
${ }^{2}$ The regression results of this analysis are available from the author.
} 
expansive strategic posture. Thus, the major conclusion of this study is that managerial attentional patterns are related to globalization strategies and to organizational outcomes.

\section{Implications of Results}

The results of the present study indicate firms were most likely to be highly global when their top management paid attention to the external environment and considered a diverse set of elements in this environment. On the other hand, firms led by top management that paid more attention to the internal environment were less likely to consider globalization as a viable strategic choice and to develop extensive global operations. These results are consistent with the view that strategic choices are determined by the cognitive processes of noticing and constructing meaning about the environment (Kiesler \& Sproull, 1982; Schwenk, 1988). Thus, as managers scan the environment, selectively notice threats and opportunities, and construct meaning about environmental trends, these processes shape strategic choices of firms. In the case of globalization strategies, the results suggest that attention to the external environment significantly influences global strategic posture of firms.

An additional support for this view is offered by the argument that managerial cognitive capabilities are especially crucial in rapidly changing environments that afford top management latitude of action or high discretion (Hambrick \& Finkelstein, 1987). Previous research suggests that high environmental discretion affects both the relationship between managerial characteristics and organizational outcomes (Finkelstein \& Hambrick, 1990; Hambrick \& Finkelstein, 1987) and managerial attention patterns (Abrahamson \& Hambrick, 1997). First, under conditions of high discretion, managerial characteristics become more important in influencing strategy (Finkelstein \& Hambrick, 1990). Second, Abrahamson and Hambrick (1997) found that in high discretion industries, attention tends to be less homogeneous across firms and reflects managerial characteristics rather than environmental constrains. Finally, Barr and colleagues (1992) reported 
that in the relatively stable low-discretion railroad industry, managers attended to similar aspects of their environment, but arrived at different interpretations. Thus, when managers operate in a relatively stable environment, variation in attentional patterns is limited and is less likely to account for variation in organizational outcomes On the other hand, in a highly dynamic environment, attention is less homogeneous and may prove to be the most crucial stage of the tripartite attentioninterpretation-action information processing sequence. Thus, in dynamic environments, managerial attention plays a much more crucial role in shaping strategic choices of firms and is more strongly reflected in organizational outcomes.

Another finding consistent with this observation pertains to the negative effect of managerial attention to the internal environment on global strategic posture. This finding suggests that top management teams that focus on "in-house" constituencies are less likely to consider global expansion as a viable strategic course. In the case of American firms, these results are not surprising because the majority of internal stakeholders-Board of Directors, owners, and top management - are predominantly American and located in the US. Therefore, attention to the internal environment can also be understood as attention to the domestic environment that predictably hinders globalization efforts.

The results of this study also contribute greater understanding of managerial attentional capabilities and patterns. First, the study provides support of the notion that attention is finite and allocated among various aspects of the environment (Sproull, 1984). Thus, top management that focused on the external environment was less likely to focus on the internal environment and vice versa. Second, top management teams also allocated their attention among various aspects of the external environment and paid more attention to customers than to any other external environmental element. Finally, consistent with prior research that firms are more likely to enter culturally familiar regions (Kogut \& Singh, 1988) this study found that top management teams of 
the sample firms paid more attention to European operations and markets than to all other regions combined.

Finally, this study provides evidence for the construct validity of managerial attention measures derived from letters to shareholders by empirically supporting theoretically predicted relationships between these measures and global strategic posture. Moreover, the absence of any reference to foreign operations and markets in a substantial number of letters (more than 25 percent) provides support for the view that letters to shareholders reflect managerial cognition and cannot be solely understood in terms of impression management. Despite ubiquitous and persistent calls advocating the competitive advantage of globalizing, a significant number of letters did not contain even a single reference to the global environment. Impression management theories, however, would have predicated that since globalization has gained the status of a "strategic must," top management would at least pay lip service to the globalization mandate. Thus, these results further validate the claim that letters to shareholders constitute a valid window into top management cognitive orientation.

\section{Limitations and Future Directions}

A general limitation of this study is related to the focus on the association between attention and action. Therefore, the study did not directly examine factors that may shape attentional patterns. Nevertheless, it offers some important insights into this issues as well as directions for future research. Managerial attentional patterns are most likely influenced by a myriad of factors, including contextual, structural, and environmental factors (Abrahamson \& Hambrick, 1997; Ocasio, 1997). Various contextual factors affect top management attentional patterns by structuring the availability, saliency, and interpretation of information (Ocasio, 1997). The current study incorporated a set of top management team heterogeneity measures to gauge the immediate decision making context. Heterogeneous team is characterized by diversity of cognitions, skills, 
and professional and social ties. Therefore, a heterogeneous team has superior socio-cognitive capabilities that enhance its ability to access a variety of information sources, pay attention to diverse elements, and process complex information (Bantel \& Jackson 1989; Ginsberg 1989; Wiersema \& Bantel 1992). At the same time, because of its diversity, the heterogeneous team may find it difficult to communicate and experience internal conflict and strain (Hambrick et al., 1996; Milliken \& Martinis, 1996; Wiersema \& Bantel 1992;). These dynamics may diminish the sociocognitive capabilities of heterogeneous team and lead to inward focus. Indeed, the results of this study suggest that the association between attentional patterns and top management team heterogeneity is not straightforward and that the various heterogeneity measures do not have a uniform impact on attention. Moreover, this association appears to be influenced by other contextual and structural factors. Thus, future research should investigate in more detail the association between top management team characteristics and various dimensions of managerial attention.

This study also incorporated two of the most significant structural characteristics of the firm that may influence managerial attention: technological intensity and global strategic posture. A high degree of technological intensity represents increases the need to pay attention to the external environment, especially to other firms that offer comparable or complementary technologies that can present a threat or opportunity to the focal firm. Similarly, expansive global strategic posture increases the need to pay attention to the global environment because of the relative importance of overseas markets and resources in the total activities of the firms. On the other hand, high technological intensity and expansive global strategic posture also requires increasing attention to internal issues such as planning, integration, coordination, and control issues ( Henderson \& Fredrickson, 1996; Roth \& O'Donnell, 1996) Thus, technological and globalization activities exert dual and often conflicting influence on managerial attention. Moreover, at any given time, these 
activities compete for attention with multiple other organizational functions. Due to information overload and the limited attentional capacity of top management, technological and globalization activities may have only a limited direct effect on top management attentional patterns. Moreover, these effects are often mediated through organizational practices that operate as attention channels (Ocasio, 1997). Thus, whether technological and/or globalization strategies become the dominant perceptual lens may depend on attention channels such as the rules, resources, and social relations within the firm (Ocasio, 1997). In other words, the relationship between structural characteristics and top management attentional patterns is imperfect and dependent upon firm-specific attention channels. This may explain why top management of firms that operate in similar industries or pursue relatively comparable strategies pay attention to different elements. Thus, future research should investigate the role of attention channels in mediating the relationship between top management attentional patterns and organizational-level structures.

Finally, this study examined attentional patterns of firms operating in highly dynamic environments. While environmental characteristics were similar, top management attentional patterns still varied across firms. Consistent with prior research (Abrahamson \& Hambrick, 1997; Ocasio, 1997), this study suggests that highly dynamic environments have only limited influence on managerial attention. Given the limited attention capacity, when the environment provides an overabundance of stimuli and top management pay attention in a selective manner. Therefore, information-saturated environments will tend to have only limited direct effect on attentional patterns. Thus, future research should examine firm-specific mechanisms that filter out information in highly dynamic environments and thereby structure attention. Again, this may explain why firms that operate in similarly dynamic industries often pay attention to different things. 


\section{REFERENCES}

Abrahamson, E., \& Fombrun, C. J. (1994). Macrocultures: Determinants and consequences. Academy of Management Review, 19, 728-755.

Abrahamson, E., \& Hambrick, D. C. (1997). Attentional homogeneity in industries: The effect of discretion. Journal of Organizational Behavior, 18, 513-532.

Aguilar, F. J. (1967). Scanning the Business Environment. New York: MacMillan.

Baltagi, B. H. (1998). Econometrics. New York: Springer.

Bantel, K. A., \& Jackson, S. E. (1989). Top Management and Innovations in Banking: Does the Composition of the Top Team Make a Difference? Strategic Management Journal, 10(Special Issue on Strategic Leadership), 107-124.

Barley, S. R., Meyer, G. W., \& Gash, D. C. (1988). Cultures of culture: Academics, practitioners, and the pragmatics of normative control. Administrative Science Quarterly, 33, 24-60.

Barr, P. S., J., Stimpert, J. L., \& Huff, A. S. (1992). Cognitive change, strategic action, and organizational renewal. Strategic Management Journal, 13, 15-36.

Bartlett, C. A., \& Ghoshal, S. (1989). Managing Across Boarders: The Transnational Solution. Boston: Harvard Business School Press.

Bartlett, C. A., \& Ghoshal, S. (1990). Matrix management: Not a structure, a frame of mind. Harvard Business Review, 68(4), 138-145.

Bartlett, C. A., \& Ghoshal, S. (1991). Global strategic management: Impact on the new frontiers of strategy research. Strategic Management Journal, 12(Special Issue), 5-16.

Berger, P. L., \& Luckmann, T. (1966). The Social Construction of Reality: A Treatise in the Sociology of Knowledge. New York: Doubleday.

Bettman, J. R., \& Weitz, B. A. (1983). Attributions in the board room: Casual reasoning in corporate annual reports. Administrative Science Quarterly, 28, 145-183.

Bourgeois, L. J., \& Singh, J. V. (1983). Organizational slack and political behavior among top management teams. Proceedings of the 43rd Annual Meeting, Academy of Management, 4347.

Bowman, E. H. (1978). Strategy, annual reports, and alchemy. California Management Review, 20(3), 64-71.

Bowman, E. H. (1984). Content analysis of annual reports for corporate strategy and risk. Interfaces, 14(1), 61-71.

Business Week. (1989, June 20). How R\&D spending pays off, 178-232. 
Calori, R., Johnson, G., \& Sarnin, P. (1994). CEO's cognitive maps and the scope of the organization. Strategic Management Journal, 15, 437-457.

Carpenter, M. A., \& Fredrickson, J. W. (2001). Top management teams, global strategic posture, and the moderating role of uncertainty. Academy of Management Journal, 44(3), 533-545.

Carpenter, M. A., Sanders, W. G., \& Gregersen, H. B. (2001). Bundling human capital with organizational context: The impact of international assignment experience on multinational firm performance and CEO pay. Academy of Management Journal, 44(3), 493-511.

Chiesa, V. (1996). Strategies for global R\&D. Research Technology Management, 39(5), 19-27.

Clapham, S. E., \& Schwenk, C. R. (1991). Self-serving attributions, managerial cognition, and company performance. Strategic Management Journal, 12, 219-229.

Daft, R. L., \& Weick, K. E. (1984). Toward a model of organizations as interpretation systems. Academy of Management Review, 9(2), 284-295.

D'Aveni, R. A., \& MacMillan, I. C. (1990). Crisis and the content of managerial communications: A study of the focus of top managers in surviving and failing firms. Administrative Science Quarterly, 35, 634-657.

DeVellis, R. F. (1991). Scale Development: Theory and Applications. Newbury Park, CA: Sage Publications.

Doz, Y. L., \& Prahalad, C. K. (1991). Managing DMNCs: A search for a new paradigm. Strategic Management Journal, 12, 145-164.

Dutton, J. E., \& Duncan, R. B. (1987). The influence of the strategic planning process in strategic change. Strategic Management Journal, 8, 103-116.

Fan, D. (1988). Predictions of Public Opinion From The Mass Media: Computer Content Analysis and Mathematical Modeling. New York: Greenwood Press.

Finkelstein, S., \& Hambrick, D. C. (1990). Top management team tenure and organizational outcomes: The moderating role of managerial discretion. Administrative Science Quarterly, 35, 484-503.

Finkelstein, S., \& Hambrick, D. C. (1996). Strategic Leadership: Top Executives and Their Effects on Organizations. St. Paul, MN: West Publishing.

Fiol, M. C. (1989). A semiotic analysis of corporate language: Organizational boundaries and joint venturing. Administrative Science Quarterly, 34, 277-304.

Fiol, M. C. (1995). Corporate communications: Comparing executives private and public statements. Academy of Management Journal, 38(2), 522-536. 
Fiske, S. T., \& Taylor, S. E. (1984). Social Cognition. Reading, MA: Addison-Wesley.

Freeman, E. (1984). Strategic Management: A Stakeholder Approach. Boston: Pitman.

Geletkanycz, M. A., \& Hambrick, D. C. (1997). The external ties of top executives: Implications for strategic choice and performance. Administrative Science Quarterly, 42, 654-681.

Ghoshal, S., \& Bartlett, C. A. (1988). Creation, adoption, and diffusion of innovations by subsidiaries of multinational corporations. Journal of International Business Studies, Fall, 365-388.

Ginsberg, A. (1989). Construing the business portfolio: A cognitive model of diversification. Journal of Management Studies, 26(4), 417-438.

Gomez-Mejia, L. R., \& Palich, L. E. (1997). Cultural diversity and the performance of multinational firms. Journal of International Business Studies, 28, 309-335.

Govindarajan, V., \& Gupta, A. (1998). .Success is all in the mindset. Financial Times, February 27.

Govindarajan, V., \& Gupta, A. (2001). The Quest for Global Dominance: Transforming Global Presence into Global competitive Advantage. San Francisco: Jossey-Bass.

Haleblian, J., \& Finkelstein, S. (1993). Top management team size, CEO dominance, and firm performance: The moderating roles of environmental turbulence and discretion. Academy of Management Journal, 36(4), 844-863.

Hambrick, D. (1982). Environmental scanning and organizational strategy. Strategic Management Journal, 3, 159-174.

Hambrick, D. C., Cho, T. S., \& Chen, M. (1996). The influence of top management team heterogeneity on firm's competitive moves. Administrative Science Quarterly, 41, 659-684.

Hambrick, D. C., \& Finkelstein, S. (1987). Managerial discretion: A bridge between polar views of organizational outcomes. Research in Organizational Behavior, 9, 369-406.

Hambrick, D. C., \& Mason, P. (1984). Upper echelons: The organization as a reflection of its top managers. Academy of Management Review, 9, 193-206.

Hansen, M. T., \& Haas. M. T. (2001). Competing for attention in knowledge markets: Electronic document dissemination in a management consulting company. Administrative Science Quarterly, 46, 1-28.

Henderson, A. D., \& Fredrickson, J. W. (1996). Information-processing demands as a determinant of CEO compensation. Academy of Management Journal, 39, 575.

Hewitt, G. K. (1980). Research and development performed abroad by US manufacturing multinationals. Kyklos, 33(2), 308-327. 
Hirst, P., \& Thompson, G. (1999). Globalization in Question (2 ${ }^{\text {nd }}$ Ed.). Cambridge: Press Polity.

Hitt, M. A., Hoskisson, R. E., \& Kim, H. (1997). International diversification: Effects on innovation and firm performance in product-diversified firms. Academy of Management Journal, 40(4), 767-798.

Hofstede, G. (1993). Cultural constraints in management theories. Academy of Management Executive, 7(1), 81-94.

Holsti, O. R. (1968). Content analysis. In L.Grdner \& E. Aronson (Eds.), The Handbook of Social Psychology (2 ${ }^{\text {nd }}$ ed., pp. 596-692). Reading, MA: Addison-Wesley.

Huff, A. S. (1990). Mapping strategic thought. In A. S. Huff (Ed.), Mapping Strategic Thought (pp. 11-49). New York: John Wiley and Sons.

Huff, A. S., \& Schwenk, C. R. (1990). Bias and sensemaking in good times and bad. In A. S. Huff (Ed.), Mapping Strategic Thought (pp. 89-108). New York: John Wiley and Sons.

Kanter, R. M. (1994). Afterword: What 'thinking globally' really means.' In R. S. Barnwik \& R. M. Kanter (Eds.), Global Strategies (pp. 227-232). Boston: Harvard Business School Press.

Kedia, B. L., \& Mukherji, A. (1999). Global managers: Developing a mindset for global competitiveness. Journal of World Business, 34(3), 0-251.

Kiesler, S., \& Sproull, L. (1982). Managerial response to changing environments: Perspectives on problem sensing from social cognition. Administrative Science Quarterly, 27, 548-570.

Kmenta, J. (1986). Elements of Econometrics. New York: Macmillan.

Kobrin, S. J. (1994). Is there a relationship between a geocentric mind-set and multinational strategy? Journal of International Business Studies, Third Quarter, 493-511.

Kogut, B., \& Singh, H. (1988). The effect of national culture on the choice of entry model. Journal of International Business Studies, Fall, 411-432.

Lant, K. T., Milliken, F. J., \& Barta, B. (1992). The role of managerial learning and interpretation in strategic persistence and reorientation: An empirical exploration. Strategic Management Journal, 13, 585-608.

Lohrke, F., \& Bruton, G. (1997). Contributions and gaps in international strategic management. Journal of International Management, 3(1), 25-57.

Michel, J. G., \& Hambrick, D. C. (1992). Diversification Posture and Top Management Team characteristics. Academy of Management Journal, 35(1), 9-37. 
Milliken, F. J., \& Martinis, L. L. (1996). Searching for Common Treads: Understanding the Multiple effect of Diversity in Organizational Groups. Academy of Management Review, 21(2), 402-433.

Murtha, T. P., Lenway, S. A., \& Bagozzi, R. P. (1998). Global mind-sets and cognitive shift in a complex multinational corporation. Strategic Management Journal, 19(2), 97-114.

Nohria, N., \& Ghoshal, S. (1997). The Differentiated Network: Organizing Multinational Corporations for Value Creation. San Francisco: Jossey-Bass Publishers.

Ocasio, W. (1997). Toward an attention-based view of the firm. Strategic Management Journal, $18,187-206$.

O'Grady, S., \& Lane, H. W. (1996). The psychic distance paradox. Journal of International Business Studies, First Quarter, 1-21.

Ohmae, K. (1989). Managing in a borderless world. Harvard Business Review, 67(3), 152-161.

Parks, R. W. (1967). Efficient estimation of a system of regression equations when disturbances are both serially and contemporaneously correlated. Journal of the American Statistical Association, 62, 500-509.

Pearce, R. D. (1993). The Growth and Evolution of Multinational Enterprise. Brookfield, VT: Edward Elgar.

Porter, M. E. (1986). Competition in Global Industries. Boston: Harvard Business School Press.

Prahalad, C. K. (1990). Globalization: The intellectual and managerial challenges. Human Resource Management, 29(1), 27-37.

Prahalad, C. K., \& Bettis, R. A. (1986). The dominant logic: A new linkage between diversity and performance. Strategic Management Journal, 7, 485-501.

Prahalad, C. K., \& Doz, Y. L. (1987). The Multinational Mission: Balancing Local Demands and Global Vision. New York: The Free Press.

Ramaswamy, K., Kroeck, G., \& Renforth, W. (1996). Measuring the degree of internationalization of a firm: A comment. Journal of International Business Studies, 27, 167-178.

Reuber, A. R., \& Fischer, E. (1997). The influence of the management team's international experience on the internationalization behavior of SMES. Journal of International Business Studies, 28, 807-825.

Rhinesmith, S. H. (1992). Global mindsets for global managers. Training and Development, 46(10), 63-69.

Ronen, S., \& Shenkar, O. (1985). Clustering countries on attitudinal dimensions: A review and synthesis. Academy of Management Review, 10(3), 435-454. 
Roth, K., \& O'Donnell, S. O. (1996). Foreign Subsidiary Compensation: An Agency Theory Perspective. Academy of Management Journal, 39(3), 678-703.

Salancik, G. R., \& Meindl, J. R. (1984). Corporate attributions as strategic illusions of management control. Administrative Science Quarterly, 29, 238-254.

Sambharya, R. B. (1996). Foreign experience of top management teams and international diversification strategies of US multinational corporations. Strategic Management Journal, 17, 739-746.

Sanders, W. G., \& Carpenter, M. A. (1998). Internationalization and firm governance: The roles of CEO compensation, top team composition, and board structure. Academy of Management Journal, 42(2), 158-178.

Sapir, E. (1944). Granding: A study in semantics. Philosophy of Science, 11, 93-116.

Schendel, D. (1991). Introduction to the special issue on global strategy. Strategic Management Journal, 12(Special Issue), 1-3.

Schwenk, C. R. (1988). The cognitive perspective on strategic decision making. Journal of Management Studies, 25(1), 41-55.

Scott, R. W., \& Meyer, J. W. (1991). The organization of societal sectors: Proposition and early evidence. In W. W. Powell \& P. J. DiMaggio (Eds.), The New Institutionalism in Organizational Analysis (pp. 108-140). Chicago: University of Chicago Press.

Smircich, L., \& Stubbart, C. (1985). Strategic management in an enacted world. Academy of Management Review, 10(4), 724-736.

Smith, K. G., Smith, K. A., Olian, J. D., Sims, H. P., O’Bannon, D. P., \& Scully, J. A. (1994). Top management team demography and process: The role of social integration and communication. Administrative Science Quarterly, 39, 412-438.

Smith, M. (1995). Computers and Human Language. New York: Oxford University Press.

Sproull, L. S. (1984). The nature of managerial attention. Advances in Information Processing in Organizations, 1, 9-27

Starbuck, W. H., \& Milliken, F. J. (1988). Executives' perceptual filters: What they notice and how they make sense. In D. C. Hambrick (Ed.), The Executive Effect: Concepts and Methods for Studying Top Managers (pp. 35-65). Greenwich, CT: JAI Press.

Stubbart, C. I. (1989). Managerial cognition: A missing link in strategic management research. Journal of Management Studies, 26(4), 325-347.

Sullivan, D. (1994). Measuring the degree of internationalization of a firm. Journal of International 
Business Studies, 25(2), 325-342.

Vernon, R. E. (1966). International investment and international trade in the product cycle. Quarterly Journal of Economics, 80(May), 190-207.

Wade, J. B., Porac, J., \& Pollock T. G. (1997). Worth, words, and the justification of executive pay. Journal of Organizational Behavior, 18(Special Issue), 641-664.

Whorf, B. L. (1956). Language, Thought and Reality: Selected Writings of Benjamin Lee Whorf. Cambridge, MA: MIT Press.

Wiersema, M. F., \& Bantel, K. A. (1992). Top Management Team Demography and Corporate Strategic Change. Academy of Management Journal, 35(1), 91-121.

Wolfe, R. A. (1994). Organizational innovation: Review, critique and suggested research directions. Journal of Management Studies, 31(3), 405-431. 
TABLE 1

Descriptive Statistics of First-Order Attention Variables*

\begin{tabular}{lcc}
\hline & MEAN & S.D. \\
\hline Board of Directors & 2.038 & 2.25 \\
Competitors & 3.94 & 3.96 \\
Customers & 6.63 & 5.95 \\
Employees & 2.9 & 3.03 \\
Dealers & .45 & 1.33 \\
Foreign-related aspects & 3.37 & 4.32 \\
Owners & 2.37 & 1.7 \\
Strategic Partners & 1.4 & 2.19 \\
Top Management & 2.66 & 2.7 \\
Africa & .004 & .28 \\
Asia-Pacific & 1.06 & 1.77 \\
Europe & 1.44 & 2.07 \\
Middle East & .004 & .23 \\
Latin America & .13 & .45 \\
North America & .16 & .48 \\
\hline & & \\
\hline
\end{tabular}

$* \mathrm{~N}=552$ 
TABLE 2

\section{Descriptive Statistics and Correlations*}

\begin{tabular}{|c|c|c|c|c|c|c|c|c|c|c|c|c|c|c|c|c|c|}
\hline & $\underline{\text { Mean }}$ & S.D. & $\underline{1}$ & $\underline{\mathbf{2}}$ & $\underline{\mathbf{3}}$ & $\underline{4}$ & $\underline{\mathbf{5}}$ & $\underline{6}$ & $\underline{7}$ & $\underline{8}$ & $\underline{9}$ & $\underline{10}$ & $\underline{11}$ & $\underline{12}$ & $\underline{13}$ & $\underline{14}$ & $\underline{15}$ \\
\hline $1 \operatorname{GSP}(\mathrm{t}+2)$ & .00 & 2.62 & & & & & & & & & & & & & & & \\
\hline 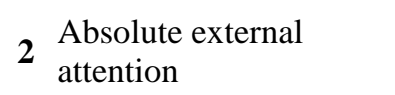 & 15.76 & 12.09 & $.35 * *$ & & & & & & & & & & & & & & \\
\hline 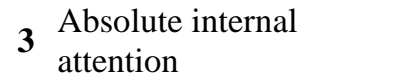 & 9.97 & 6.6 & $.42 * *$ & $.42 * *$ & & & & & & & & & & & & & \\
\hline $4 \begin{array}{l}\text { Absolute external } \\
\text { attention breadth }\end{array}$ & 3.38 & 1.62 & $.27 * *$ & $.63^{* *}$ & $.23 * *$ & & & & & & & & & & & & \\
\hline $5 \begin{array}{l}\text { Proportionate external } \\
\text { attention }\end{array}$ & .01 & .00 & $.30 * *$ & $.57 * *$ & -.01 & $.45^{* *}$ & & & & & & & & & & & \\
\hline $6 \begin{array}{l}\text { Proportionate internal } \\
\text { attention }\end{array}$ & .01 & .01 & .004 & $-.26 * *$ & $.49 * *$ & $-.27 * *$ & $-.11 * *$ & & & & & & & & & & \\
\hline $7 \begin{array}{l}\text { Proportionate external } \\
\text { attention breadth }\end{array}$ & .56 & 18 & $.21 * *$ & $.40 * *$ & $.17 * *$ & $.79 * *$ & $.34 * *$ & $-.20 * *$ & & & & & & & & & \\
\hline 8 Technological intensity & .01 & .06 & .02 & .11 & .07 & -.06 & .08 & -.03 & $-.09 *$ & & & & & & & & \\
\hline 9 Organizational slack & -.02 & 0.46 & $-.25 * *$ & $-.11 *$ & $-.16^{* *}$ & $-.10 *$ & -.09 & .01 & -.08 & $.36 * *$ & & & & & & & \\
\hline 10 Firm size & 5.56 & 2.33 & $.63 * *$ & $.30 * *$ & $.37 * *$ & $.22 * *$ & $.14 * *$ & $.10^{*}$ & $.21 * *$ & .03 & $-.15^{* *}$ & & & & & & \\
\hline 11 GSP (t) & .00 & 2.58 & $.97 * *$ & $.33 * *$ & $.24 * *$ & $.25^{* *}$ & $.30 * *$ & .03 & $.20 * *$ & -.03 & $-.25 * *$ & $.59 * *$ & & & & & \\
\hline 12 TMT size & 4.79 & 3.24 & $.53 * *$ & $.28 * *$ & $.25 * *$ & $.24 * *$ & $.12 * *$ & -.01 & $.19 * *$ & -.04 & $-.24 * *$ & $.55 * *$ & $.54 * *$ & & & & \\
\hline 13 Tenure hetero. & .457 & .34 & .09 & .05 & $.16^{* *}$ & .02 & -.03 & $.12 *$ & $.11 *$ & $-.21 * *$ & $-.21 * *$ & .03 & $.10^{*}$ & $.24 * *$ & & & \\
\hline 14 Age hetero. & .12 & .07 & $-.13 *$ & .14 & .01 & $.17 * *$ & -.01 & $-.11 *$ & $.15^{* *}$ & .01 & .00 & $-.14 * *$ & $-.10 *$ & .45 & $.30 * *$ & & \\
\hline $\begin{array}{l}\text { Functional background } \\
\text { hetero. }\end{array}$ & .53 & .26 & $.30 * *$ & $.18^{*}$ & $.17 * *$ & $.16^{* *}$ & -.04 & $.15^{* *}$ & .03 & $-.10 * *$ & $-.30 * *$ & $.34 * *$ & $.32 * *$ & $.58 * *$ & $.11^{*}$ & $.11 *$ & \\
\hline $16 \begin{array}{l}\text { Educational specialty } \\
\text { hetero. }\end{array}$ & .41 & .25 & $.28 * *$ & $.24 * *$ & $.22 * *$ & $.20 * *$ & -.29 & -.08 & $.14^{* *}$ & -.05 & $-.28 * *$ & $.38 * *$ & $.30 * *$ & $.58 * *$ & $.20 * *$ & $.30 * *$ & $.53 * *$ \\
\hline
\end{tabular}

\footnotetext{
* Variables 1-12: $\mathrm{N}=552 ;$ Variables 13-16: $\mathrm{N}=448 ; \mathrm{p}<.05 ; * * \mathrm{p}<.01$
} 
TABLE 3

Summary of GLS Regression Results: Dependent Variable is Global Strategic Posture at $\mathbf{t}+2 *$

\begin{tabular}{|c|c|c|c|c|c|c|}
\hline & $\begin{array}{c}\text { Model 1: } \\
\text { Controls } \\
\text { (Full Sample) }\end{array}$ & $\begin{array}{c}\text { Model 2: } \\
\text { Absolute } \\
\text { Attention } \\
\text { (Full Sample) }\end{array}$ & $\begin{array}{c}\text { Model 3: } \\
\text { Proportionate } \\
\text { Attention } \\
\text { (Full Sample) }\end{array}$ & $\begin{array}{c}\text { Model 4: } \\
\text { Controls } \\
\text { (Sub-sample) }\end{array}$ & $\begin{array}{c}\text { Model 5: } \\
\text { Absolute } \\
\text { Attention } \\
\text { (Sub-sample) }\end{array}$ & $\begin{array}{c}\text { Model 6: } \\
\text { Proportionate } \\
\text { Attention } \\
\text { (Sub-sample) }\end{array}$ \\
\hline Intercept & $\begin{array}{c}.068 \\
(.188)\end{array}$ & $\begin{array}{c}.239 * * * \\
(.056)\end{array}$ & $\begin{array}{c}.022 \\
(.328)\end{array}$ & $\begin{array}{c}.363 \\
(.304)\end{array}$ & $\begin{array}{c}.253 \\
(.375)\end{array}$ & $\begin{array}{c}.362 \\
(.380)\end{array}$ \\
\hline \multicolumn{7}{|l|}{ Main Effects } \\
\hline External attention & & $\begin{array}{c}.004 * * * \\
(.000)\end{array}$ & $\begin{array}{c}5.333 * * * \\
(.849)\end{array}$ & & $\begin{array}{c}.003 * * * \\
(.001)\end{array}$ & $\begin{array}{c}4.103 * * * \\
(.797)\end{array}$ \\
\hline External attention breadth & & $\begin{array}{c}.026 * * * \\
(.000)\end{array}$ & $\begin{array}{c}.219 * * * \\
(.048)\end{array}$ & & $\begin{array}{l}.049 * * \\
(.016)\end{array}$ & $\begin{array}{l}.159 * \\
(.082)\end{array}$ \\
\hline Internal attention & & $\begin{array}{c}-.004 * * * \\
(.000)\end{array}$ & $\begin{array}{l}-2.683 * \\
(1.328)\end{array}$ & & $\begin{array}{c}-.004 * * \\
(.002)\end{array}$ & $\begin{array}{c}.909 \\
(2.73)\end{array}$ \\
\hline \multicolumn{7}{|l|}{ Controls } \\
\hline Technological intensity & $\begin{array}{c}-1.013 * * * \\
(.277)\end{array}$ & $\begin{array}{c}-.968 * * * \\
(.284)\end{array}$ & $\begin{array}{l}-.626^{*} \\
(.269)\end{array}$ & $\begin{array}{c}.443 \\
(.314)\end{array}$ & $\begin{array}{c}.673 \\
(.351)\end{array}$ & $\begin{array}{c}.416 \\
(.406)\end{array}$ \\
\hline Organizational slack & $\begin{array}{c}.041 \\
(.043)\end{array}$ & $\begin{array}{c}.114 * * * \\
(.006)\end{array}$ & $\begin{array}{l}.199 * * \\
(.067)\end{array}$ & $\begin{array}{c}.122 * * * \\
(.036)\end{array}$ & $\begin{array}{l}.266^{*} \\
(.128)\end{array}$ & $\begin{array}{c}.084 \\
(.068)\end{array}$ \\
\hline Firm size & $\begin{array}{l}.068 * * \\
(.026)\end{array}$ & $\begin{array}{c}.029 * * * \\
(.006)\end{array}$ & $\begin{array}{c}.051 \\
(.045)\end{array}$ & $\begin{array}{c}.033 \\
(.028)\end{array}$ & $\begin{array}{l}-.026 \\
(.042)\end{array}$ & $\begin{array}{l}-.010 \\
(.043)\end{array}$ \\
\hline Global strategic posture (t) & $\begin{array}{c}.919 * * * \\
(.022)\end{array}$ & $\begin{array}{c}.919 * * * \\
(.000)\end{array}$ & $\begin{array}{c}.938 * * * \\
(.027)\end{array}$ & $\begin{array}{c}.918 * * * \\
(.029)\end{array}$ & $\begin{array}{c}.989 * * * \\
(.043)\end{array}$ & $\begin{array}{c}.920 * * * \\
(.042)\end{array}$ \\
\hline TMT size & $\begin{array}{c}.006 \\
(.004)\end{array}$ & $\begin{array}{c}.004 * * * \\
(.000)\end{array}$ & $\begin{array}{c}.007 \\
(.008)\end{array}$ & $\begin{array}{c}.019 \\
(.009)\end{array}$ & $\begin{array}{l}-.017 \\
(.022)\end{array}$ & $\begin{array}{c}.011 \\
(.019)\end{array}$ \\
\hline Tenure hetero. & & & & $\begin{array}{c}.154 * * * \\
(.037)\end{array}$ & $\begin{array}{c}.213 \\
(.112)\end{array}$ & $\begin{array}{c}.107 \\
(.096)\end{array}$ \\
\hline Age hetero. & & & & $\begin{array}{c}-1.286 * * * \\
(.277)\end{array}$ & $\begin{array}{l}-.661 \\
(.514)\end{array}$ & $\begin{array}{c}-1.175^{* *} \\
(.446)\end{array}$ \\
\hline Functional background hetero. & & & & $\begin{array}{c}.011 \\
(.228)\end{array}$ & $\begin{array}{c}.118 \\
(.379)\end{array}$ & $\begin{array}{c}.216 \\
(.326)\end{array}$ \\
\hline Educational specialty hetero. & & & & $\begin{array}{c}-.183 * * \\
(.063)\end{array}$ & $\begin{array}{c}.254 \\
(.292)\end{array}$ & $\begin{array}{l}-.132 \\
(.197)\end{array}$ \\
\hline
\end{tabular}

$* \quad * \mathrm{p}<.05 ; * * \mathrm{p}<.01 ; * * * \mathrm{p}<.001$. Unstandardized regression coefficients. Standard errors are in parentheses.

** $\mathrm{N}=552$

$* * * \quad \mathrm{~N}=448$ 


\section{SIDEBAR}

\section{Organizational Context}

\section{External Environment}

In the mid-1980s, the term "globalization" has forcefully emerged in public and academic discourse. Advances in communication and technology were among the major forces identified as driving globalization and integration of the major national economies. Top management of US firms were increasingly encouraged to globalize their operations and markets as globalization was conceived as inevitable. By the early 1990s, a growing number of companies began to view globalization as offering significant opportunities for growth and profitability. The catchphrase "go global" has nearly gained the status of a "strategic must" and top management of US companies faced the challenge of expending their international operations and responding to intensified global competition.

\section{The companies}

The companies were drawn from three, comparably globalized, US manufacturing industries: computer equipment, semiconductors, and pharmaceuticals. In 1987, first year of the study, the companies sold, on average, 28 per cent of their output in foreign markets. However, 14 out of the 69 companies in the sample sold less that 10 per cent of their output in foreign markets, thus not yet responding to the ubiquitous and persistent calls to "go global." In 1996, ten years later, the companies sold, on average, 42 per cent of their output in foreign markets and were also more global in term of their assets and countries of operations. Still, seven companies did not develop any global presence. While all industries experienced growth in foreign sales over the ten-year period, there were inter-industry differences. The semiconductor companies experienced the most significant growth and doubled their foreign sales in ten years; the computer equipment companies experienced more moderate growth and increased their foreign sales in 36 per cent; the 
pharmaceutical companies increased their foreign sales in 15 per cent only. Nevertheless, the industries remained comparably globalized throughout the ten-year period.

\section{Top management team}

The demographic profile of the top management teams was as follows. The average age of team members was 52 and the teams were relatively homogenous age-wise; the average tenure was 13 years and the teams were more diverse tenure-wise; the dominant education specialty was Sciences

and the dominant functional background was general management. A surprisingly small number of executives had any international experience. The team members were predominantly males. 


\section{APPENDIX}

\section{CONTENT ANALYSIS PROCEDURE}

The process of content analysis involved both manual and computer-aided coding. The dictionary construction process began with manual coding of 226 letters to shareholders published by firms in the three target industries using Atlas/ti, qualitative content analysis software. The manual coding followed a modified content analysis procedure originally developed by D'Aveni and MacMillan (1990), who developed an extensive content analysis codebook specifically for coding shareholders letters. In this process, the unit of analysis, or recording unit, was a sentence. Each sentence was read carefully and was either not coded, coded as a reference to one concept, or coded as a reference to more than one concept if applicable. For the purpose of dictionary construction, sentences that were coded as a reference for more than one concept were excluded from further analysis. This process generated 4,373 sentences that were then treated as separate records and were grouped into 11 concept-specific sets. In the dictionary, the Customer category was broken down into three industry-specific subsets, reflecting the fact the three industries under study often refer to their customers in a very different language.

The concept-specific sets of records, which constituted the raw data of the dictionary, were then uploaded into WORDSTAT - a quantitative content analysis package — in order to conduct a detailed analysis of word and phrases underlying each concept. WORDSTAT provides several outputs, including frequencies of target words and phrases, crosstabulation of categories by words and phrases, and statistical analysis. The first output of WORDSTAT is a frequency list of all words in each concept-specific set. This list was slowly trimmed by removing non-diagnostic items to an exclusion list, resulting in a tentative inclusion list. The second output of WORDSTAT is a frequency of words in the inclusion list from which concept-specific dictionary items were 
generated. The third output is a crosstabulation of words and phrases in the inclusion list by concept.

Through careful review of the crosstab list, concept-specific items, i.e., words that concentrated around a specific concept and therefore potentially diagnostic, were identified. These items then became tentative members of their respective categories and were included in the dictionary for further analysis. Each of the concept-specific items was subjected to a detailed analysis that included retrieving the actual record from which the items were generated and keyword-in-context (KWIC) analysis. Several high frequency domain-specific items, such as 'market,' 'management,' and 'corporate' were scattered across all categories and presented a special challenge. These words were potentially significant as indicated by their high frequency, but non-diagnostic as indicated by their distributions across categories. These words were subjected to meticulous KWIC analysis in order to identify phrases that would clarify their lexical membership. Thus, items such as 'market share' and 'market position' were generated through KWIC analysis of the word 'market' and identified as members of the Competitors category; items such as 'top management' and 'corporate management' were generated through KWIC analysis of 'management' and identified as members of the Top Management category. In addition, a list of countries by regions was included as a supplement. Finally, the constructed dictionary was subjected to statistical analyses to assess the association between lexical items and the nine firstorder orientation concepts. 